\title{
Genetics of autism spectrum disorder \& BDNF gene
}

\author{
Usha P Dave \\ From International Conference on Human Genetics and 39th Annual Meeting of the Indian Society of \\ Human Genetics (ISHG) \\ Ahmadabad, India. 23-25 January 2013
}

Autism is a group of complex neurodevelopmental disorders which manifests problems with social interaction, language, communication and behavior deficits like stereotype and repetitive activities. Autism prevalence rate in last one decade has shown astonishing level of increase from 1 per 10,000 to 1 in 110 children in USA (CDC, 2007). Various environmental \& genetic factors or combination are suggested as contributing factors in this clinically diagnosed neurobehaviour syndrome. However, similar data on prevalence are scarce in India. The etiology of autism still remains unknown, with many factors implicated in the development of autism phenotype. Autism Spectrum Disorder (ASD) is evaluated by a clinical psychologist using DSMR- IV criteria \& may manifest mild to severe autistic features, clinical symptoms \& low to high intellectual functioning. There are few well characterized genetic/ metabolic conditions (e.g. Rett Syndrome, Tuberous sclerosis, PKU) and chromosomal syndromes (e.g. Fragile-X, Angelman and Prader willi ) where autism has frequently associated features. Multiple genes are thought to be involved in the pathogenesis, but no evidence involving any one particular gene. The recent research focus is also on epigenetic mechanisms operating in complex autism.

Brain Derived Neurotrophic Factor (BDNF) is a neurotophin in the mammalian Central Nervous System \& important in neuronal survival, neurogenesis, and synaptic plasticity. BDNF gene is located on chromosome 11. In humans, Val66Met is probably the most investigated SNP of the BDNF gene. Since BDNF readily crosses the Blood-Brain-Barrier, the serum concentrations correlate directly to brain concentration, therefore plasma studies of BDNF are thought to accurately reflect CNS concentration. The significance of serum BDNF in ASD to explore

Correspondence: ushadave26@gmail.com

Medical Geneticist \& Neuroscientist, Mumbai, India its precise role in pathogenesis of ASD and therapeutic relevance is increased with the evidence of BDNF linked with autism. A genetically heterogeneous population of India where consanguinity and endogamous marriages are prevalent genetic risk factors, ASD is a challenge. An attempt is made to study BDNF level \& mutations in correlation with the severity of neurobehavioral deficits in Indian patients with ASD \& mental retardation. This will be discussed in the light of current scenario.

Published: 21 January 2014

doi:10.1186/1755-8166-7-S1-O3

Cite this article as: Dave: Genetics of autism spectrum disorder \& BDNF gene. Molecular Cytogenetics 2014 7(Suppl 1):03.

\author{
Submit your next manuscript to BioMed Central \\ and take full advantage of: \\ - Convenient online submission \\ - Thorough peer review \\ - No space constraints or color figure charges \\ - Immediate publication on acceptance \\ - Inclusion in PubMed, CAS, Scopus and Google Scholar \\ - Research which is freely available for redistribution

C Biomed Central

(c) 2014 Dave; licensee BioMed Central Ltd. This is an Open Access article distributed under the terms of the Creative Commons Attribution License (http://creativecommons.org/licenses/by/2.0), which permits unrestricted use, distribution, and reproduction in any medium, provided the original work is properly cited. The Creative Commons Public Domain Dedication waiver (http:// creativecommons.org/publicdomain/zero/1.0/) applies to the data made available in this article, unless otherwise stated. 